\title{
The influence of dietary advice on nutrient intake during pregnancy
}

\author{
BY ANNIE S. ANDERSON* AND DORIS M. CAMPBELL \\ Department of Obstetrics, University of Aberdeen, Aberdeen Maternity Hospital, Cornhill Road, \\ Aberdeen
}

AND RICHARD SHEPHERD

Food Choice Section, Consumer Sciences Department, AFRC Institute of Food Research, Reading Laboratory, Earley Gate, Whiteknights Road, Reading

(Received 5 March 1993 - Revised 27 May 1994-Accepted 7 June 1994)

\begin{abstract}
To assess the effect of an antenatal nutrition programme designed specifically for the local population, questionnaires on nutrition knowledge, attitudes to healthier eating and $4 \mathrm{~d}$ diet diaries were completed by women attending routine antenatal clinics. Women who received the nutrition education programme were allocated into an Intervention Education Group whilst those women who did not were allocated into a Routine Education Group. The results showed that knowledge about nutrition was significantly higher in the intervention group. However, no significant differences were detected between the two groups for attitude variables or nutrient intake. It is concluded, therefore, that the most-widely-read form of nutrition advice for pregnant women may have some impact on nutrition knowledge but has little effect on nutrient intake during pregnancy.
\end{abstract}

Dietary advice: Nutrient intake: Pregnancy

Many people view pregnancy as an ideal time to promote healthier lifestyles for the benefit of the new baby (Waterson \& Murray-Lyon, 1989), the immediate family (Allard, 1986) and the wider community (Metzler \& Griffith, 1981). Dietary change is often viewed as a cornerstone to better health (Stevens, 1990) and has been linked with pregnancy in areas ranging from reduction in congenital disorders (Smithells et al. 1977) to heartburn (Davison et al. 1970). There are a number of reasons why pregnancy might be a suitable time for encouraging dietary change. First, women might change what they eat during pregnancy because of physical symptoms and would welcome any advice which will alleviate these; second, they are responsive to health advice at this time (Eaton, 1984); and third, they may actively seek health information (Eiser \& Eiser, 1985). The antenatal care system provides an excellent opportunity to reach large numbers of healthy women and, thus, influence the health of the next generation.

The effect of dietary advice alone (i.e. providing information on appropriate food choices) without giving any dietary supplements (i.e. foods such as orange juice or milk or vitamin and mineral supplements) on encouraging healthy eating habits during pregnancy has rarely been examined (Kafatos et al. 1989; Olsen et al. 1989). However, it may be that previous dietary education programmes have failed to take account of local food selections and factors which influence these.

Formative research surveys in Aberdeen have shown that the nutrient intake of pregnant

* Present address: University of Glasgow, Department of Human Nutrition, Glasgow Royal Infirmary, Alexandra Parade, Glasgow G31 2ER. 
women was high in fat (42 (SD 5) \% of energy from fat) and low in carbohydrate (43 (SD 5) \% of energy) and dietary fibre (18 \pm (SD 6) g) (Anderson, 1991). Our programme targeted specific foods identified by examining food selections in women with a high fat intake compared with those with a low fat intake. For example, higher intakes of breakfast cereals, fruit juice and potatoes (baked and boiled), and lower intakes of full-fat milk, chips, crisps, spreading fats, cakes and pastries were encouraged.

Work on attitudes and beliefs within the same population (Anderson \& Shepherd, 1991) suggested that relating healthier eating to health maintenance and family concern might assist behavioural change. It also suggested that doctors and family exert considerable social pressure and assist in the promotion of healthy nutrition. Research on women's opinions of currently available dietary advice showed that confusion between diet for pregnancy and diet for long-term health needed to be addressed. Nutrition knowledge and nutrition behaviour may not necessarily be positively associated. Information may be disregarded, altered, or even be used to justify existing behaviour. Thus, many nutrition educators feel that nutrition knowledge functions as a tool only if individuals are ready to change (Parraga, 1990). Attitude change must mediate the process. That is, a person must have knowledge of information but also feel it is important (belief). A major methodological problem has been the failure to apply well validated and theoretically sound measures of attitudes and beliefs (Shepherd, 1989). One of the most extensively applied models is that developed by Ajzen \& Fishbein (1980) which offers a framework for the generation of questions, the scoring of responses and for testing the relationships between beliefs, attitudes, intentions and behaviour; it has been very widely used and has shown good predictive power for a variety of behaviours (for discussion and examples, see Ajzen \& Fishbein, 1980; see also Tesser \& Shaffer, 1990). It has been used in many studies examining the reasons for the selection of foods (Shepherd \& Stockley, 1985, 1987; Shepherd, 1989; Schifter \& Ajzen, 1985; Tuorila, 1987), and has demonstrated strong relationships between attitudes, beliefs and food choice. This demonstrates the advantages of applying structured attitude models rather than relying on ad hoc measures of attitudes and beliefs.

The aim of the current study was to test the response of pregnant women to dietary advice by comparing the nutrition knowledge, attitudinal variables to healthier eating and nutrient intake in a group of women receiving routine antenatal clinic dietary education (Routine Education Group; REG) and a group who also received a special intervention education programme (Intervention Education Group; IEG). The present paper does not address dietary differences between pregnant and non-pregnant women which is reported elsewhere (Anderson et al. 1993).

\section{METHODS}

The study was designed in three stages: (1) development of nutrition education material for dietary advice; (2) development of assessment measures for (a) nutrition knowledge, (b) attitudes to healthy eating, (c) nutrient intake; (3) controlled trial of nutrition advice.

\section{Development of nutrition education material for dietary advice}

A preliminary survey amongst dietitians working in Scotland showed that all antenatal clinics use written methods for providing nutritional information for pregnant women. Although personal consultations, videos and antenatal classes are used, these are not available routinely. Dietary advice booklets and information sheets were reviewed but none was found to address all current nutrition topics suitable for the promotion of family health, thus material was produced specifically for the present study.

The education programme developed for the study was entitled 'Food for Life' and was presented as two information packs. The first comprised a self-assessment quiz, an 
information booklet, and a shopping list pad which were contained in an envelope decorated with 'Food for Life' stickers. The second pack comprised a personalized letter promoting healthier eating during pregnancy from a named doctor, recipe leaflet with recipes for healthy family meals, enclosed in an envelope decorated with 'Food for Life' stickers. Additionally, pregnant women received the routine nutrition education material available for pregnant women in Aberdeen which comprises one page in a general pregnancy health guide (The Book of the Child, Scottish Health Education Group, 1980).

\section{Development of assessment measures}

Nutrition knowledge. A nutrition knowledge questionnaire based on a test described by Anderson et al. (1988) was developed. Nineteen questions were presented in multiple choice format. Knowledge of three main topics was tested: nutrition terms, theoretical principles of nutrition, practical application. Eight addressed issues relating nutrients and health (e.g. 'To help improve the nation's health, do you think that people should (a) stop eating dietary fibre (b) eat more dietary fibre (c) eat less dietary fibre (d) start eating dietary fibre (e) don't know'). The remaining eleven addressed issues relating foods and health (e.g. 'To help improve the nation's health, how much bread (white, brown and wholemeal) do you think people should eat? (a) the same amount as they do at present (b) more (c) less (d) none (e) don't know'). The questionnaire was designed for self-completion in the presence of a researcher.

Five pilot studies were conducted in order to develop this questionnaire. These used logical analysis procedures to rate possible topics for inclusion (content validity). Phrasing was based on that suggested by Oppenheim (1966) and tested for face validity (Talmage \& Reisner, 1981). Criterion validity was assessed by examining the percentage of correct answers achieved for each item by a group similar in age and sex who were believed to have a good knowledge of nutrition (nutrition undergraduates). Difficulty and discrimination indices (Nunnally, 1983) were calculated for each question.

Attitudes to healthier eating. The attitudinal questionnaire was based on the Fishbein \& Ajzen (1975) 'theory of reasoned action model' (Fig. 1) and was extensively pilot tested in the local population. In this model, behaviour (healthier eating) is said to be predicted by behavioural intention, which in turn is predicted by two components: direct attitude (feeling towards healthier eating) and direct subjective norm (social pressure to try healthier eating). In turn, estimated attitudes (function of behavioural beliefs about healthier eating modified by the person's evaluations of these beliefs) were considered predictive of direct attitudes. Likewise, direct subjective norms were predicted by estimated subjective norms (function of normative beliefs about whether the individual feels that specific other people think the respondent should try healthier eating, modified by the respondent's motivation to comply with the wishes of that referent).

To measure these components, questions and responses were designed as follows: (1) behavioural intention: respondents were asked to rate their agreement/disagreement toward the statement ' $I$ intend to try healthier eating' using response scales labelled 'strongly agree' and 'strongly disagree' at extreme ends; (2) direct attitude: four questions which described 'healthier eating' as beneficial, good, pleasant and desirable were presented. These were rated using response scales labelled 'strongly agree' and 'strongly disagree' at extreme ends; (3) direct subjective norm: this was assessed by two questions, i.e. 'Most people who are important to me "think I should try' or 'be concerned about' healthier eating'. The response scales of these questions were labelled at extreme ends 'strongly agree' and 'strongly disagree'; (4) estimated attitude: this was assessed by constructing six pairs (one of each behaviour belief and outcome evaluation) of statements on the relationship between 'healthier eating' and increased food preparation, eating 


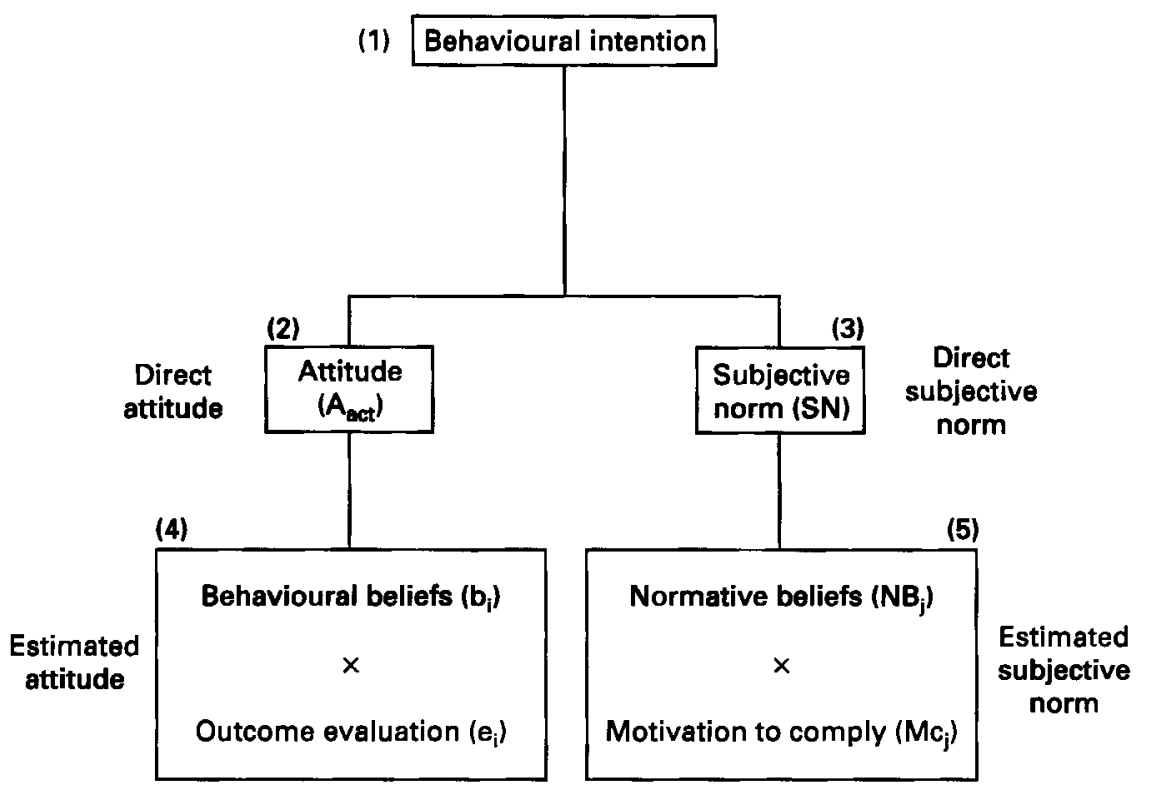

(1) Behavioural intention is used as a measure of behaviour.

(2) Attitude or personal feelings.

(3) Social pressure from other persons.

(4) Predictors of attitude component (estimated attitude).

(5) Predictors of subjective norm component (estimated subjective norm).

Fig. 1. Relationship between attitudinal components based on the Fishbein \& Ajzen (1975) theory of reasoned action model. Behavioural intention $=\beta_{1} \times \mathrm{A}_{\text {act }}+\beta_{2} \times \mathrm{SN}$, where $\beta_{1}$ and $\beta_{2}$ are relative weightings derived from multiple-regression analysis, $A_{a c t}=\Sigma b_{1} \times e_{i}$ and $S N=\Sigma N B_{j} \times M c_{j}$.

expensive foods, poor (unappealing) taste, eating differently from the rest of the family, maintaining health and reducing the risks of coronary heart disease. The belief statements were assessed on the scale 'strongly agree' to 'strongly disagree' and corresponding evaluation statements on the scale 'very desirable' to 'very undesirable'; (5) estimated subjective norm: this was assessed by four pairs of statements (one each for normative belief and motivation to comply) which queried whether the respondent thought her doctor/partner/family/friends would like her to try healthier eating, and the respondent's motivation to comply. Statements on normative beliefs were assessed on the scale 'strongly disagree' to 'strongly agree' and corresponding motivation to comply on the scale of 'wishing to do' or 'not to do'.

The questionnaire comprised twenty-seven questions preceded by a definition of healthier eating as: 'healthier eating means increasing your intake of fibre-rich foods such as bread, potatoes, cereals and fruits and decreasing your intake of food high in fat, such as dairy products, meat products, and fried food'.

Pilot studies assessed content validity, face validity and internal reliability. The main tests and results are published elsewhere (Anderson \& Shepherd, 1989).

Dietary intake. In pregnancy, dietary intake was assessed prospectively. Women were invited to record all food and drink consumed over a $4 \mathrm{~d}$ period (Edington et al. 1989), covering two weekend days and two week days. Portions were described using household measures and food photographs. Cross-check questions designed to gain qualitative and quantitative data about fifteen main food groups were also included. The diet books were 
Table 1. Response rate for intervention study to assess the effect of an antenatal nutrition education programme designed specifically for the local population

\begin{tabular}{lcc}
\hline \hline Study group*... & $\begin{array}{c}\text { Intervention } \\
\text { Education Group }\end{array}$ & $\begin{array}{c}\text { Routine } \\
\text { Education Group }\end{array}$ \\
\hline No. identified for study & 164 & 164 \\
No. failing to participate & 22 & 18 \\
Reasons for failure: & & 5 \\
Miscarriage/abortion & 6 & 5 \\
Delivered before 28 weeks & 5 & 4 \\
Left the area & 5 & 2 \\
Refusals & 3 & 1 \\
Unable to trace & 2 & 1 \\
Booked too late for inclusion & 1 & $146 \dagger$ \\
No. returning questionnaire & $142 \dagger$ & $114 \ddagger$ \\
No. returning diet diaries & 111 & \\
\hline
\end{tabular}

* Intervention Education Group received the nutrition education programme, while the Routine Education Group did not receive the nutrition education programme.

$\dagger$ One person failed to complete the knowledge questionnaire, one person failed to complete the attitude questionnaire.

$\ddagger$ One person returned a diary which was then excluded from analysis.

returned, checked for completion, coded and analysed for nutrient intake using a nutritional database of standardized food tables (Paul \& Southgate, 1978), supplementary tables (Wiles et al. 1980; Tan et al. 1985), recipes for local dishes and food manufacturers' data. The mean daily nutrient intake for the diary data was calculated using the following equation:

$\underline{\text { (mean weekday intake } \times 5)+ \text { weekend day } 1 \text { intake }+ \text { weekend day } 2 \text { intake }}$ 7

\section{Controlled trial of nutrition advice}

All women attending antenatal booking clinics at Aberdeen Maternity Hospital between November 1987 and October 1988 were allocated to the IEG or the REG. In order to produce two similar groups of women, one midwife was responsible for allocating women with unit numbers ending in digits 1-5 (inclusive) to the IEG and women with unit numbers ending in 6-0 (inclusive) to the REG. (This allocation process was not made known until all the results were collected and analysed.) All women received routine education material but the IEG also received the first education package from the midwife. At 26 weeks gestation all women in the IEG received their second pack posted to them personally. All women, IEG and REG, returned for their routine clinic visit at about 30 weeks and were invited to participate by completing the specific knowledge and attitudinal questionnaires and by recording their food intake.

\section{Statistical methods}

Two tailed $t$ tests were used to examine the difference between mean scores for nutrition knowledge, attitude and dietary intake in the REG and IEG. The Chi-square test was used to test the differences in frequency between achievers and non-achievers of dietary goals. Multiple-regression analysis was used to assess the variance in behavioural intention accounted for by attitude and subjective norm. 
Table 2. Characteristics of subjects participating in the intervention education study to assess the effect of an antenatal nutrition education programme designed specifically for the local population

\begin{tabular}{|c|c|c|c|c|c|}
\hline \multirow[t]{2}{*}{$\begin{array}{l}\text { Study group*... } \\
n \ldots\end{array}$} & \multicolumn{2}{|c|}{$\begin{array}{c}\text { Intervention } \\
\text { education group } \\
141\end{array}$} & \multicolumn{2}{|c|}{$\begin{array}{l}\text { Routine } \\
\text { education group } \\
145\end{array}$} & \multirow{2}{*}{$\begin{array}{l}\text { Statistical analysis } \\
\text { of difference } \\
\text { between groups }\left(x^{2}\right)\end{array}$} \\
\hline & No. & $\%$ & No. & $\%$ & \\
\hline \multicolumn{6}{|l|}{ Marital status } \\
\hline Single & 12 & 9 & 11 & 8 & $x^{2} 1.5$ \\
\hline Married & 104 & 74 & 109 & $74 \cdot 5$ & df 5 \\
\hline Divorced & 1 & $0 \cdot 5$ & 0 & 0 & NS \\
\hline Separated & 1 & 0.5 & 1 & 0.5 & \\
\hline Cohabiting & 16 & 11 & 14 & 10 & \\
\hline Information missingt & 7 & 5 & 10 & 7 & \\
\hline \multicolumn{6}{|l|}{ Social class } \\
\hline I-III nm & 47 & 33 & 42 & 30 & $x^{2} 1 \cdot 3$ \\
\hline III $m-V$ & 62 & 44 & 73 & 50 & df 2 \\
\hline Information missing & 32 & 23 & 30 & 20 & NS \\
\hline \multicolumn{6}{|l|}{ Parity } \\
\hline 0 & 80 & 57 & 64 & 44 & $x^{2} 4 \cdot 8$ \\
\hline $1+$ & 52 & 37 & 72 & 50 & df 2 \\
\hline Information missing\& & 9 & 6 & 9 & 6 & NS \\
\hline \multicolumn{6}{|l|}{ Smoking } \\
\hline Non-smoker & 83 & 59 & 79 & 55 & $x^{2} 0.6$ \\
\hline Smoker & 44 & 31 & 47 & 32 & df 2 \\
\hline Information missing $\|$ & 14 & 10 & 19 & 13 & NS \\
\hline \multicolumn{6}{|l|}{ Age (years) } \\
\hline $15-20$ & 18 & 13 & 6 & 4 & $\chi^{2} 8 \cdot 0$ \\
\hline $21-30$ & 94 & 67 & 98 & 68 & df 2 \\
\hline $31+$ & 29 & 21 & 41 & 28 & $P<0.05$ \\
\hline Information missing & 0 & 0 & 0 & 0 & \\
\hline
\end{tabular}

NS, not significant.

* Intervention education group received the nutrition education programme, while the routine intervention group did not receive the nutrition education programme.

$\dagger$ Seventeen women failed to deliver babies at Aberdeen Maternity Hospital so no details are available for these women.

$\ddagger$ In addition forty-seven women had missing information for social class (based on the occupation of partner/husband) because they claimed to have no partner $(n 26)$ or their partner/husband was unemployed, a full-time student or serving in HM Forces and, therefore, not classified.

$\S$ Details for parity were not available for one case.

$\|$ Ten women declined to give information on smoking habits.

\section{Ethics}

Ethical approval was given for this study by the Joint Ethical Committee of Grampian Health Board and The University of Aberdeen.

\section{RESULTS}

Three hundred and twenty-eight women were recruited. Similar numbers in each group returned questionnaires and diet diaries (Table 1). Marital status, social class (divided into non-manual and manual groups defined by occupation of husband/partner), parity and smoking habit were similar in both groups (Table 2), although age at delivery was significantly higher in the REG. 
Table 3. Nutrition-knowledge-component scores for groups of subjects participating in the nutrition education study to assess the effect of an antenatal nutrition education programme designed specifically for the local population

(Mean values and standard deviations)

\begin{tabular}{|c|c|c|c|c|c|c|c|c|}
\hline \multirow[t]{2}{*}{ Study group $\nmid \ldots$} & \multicolumn{3}{|c|}{$\begin{array}{c}\text { Intervention } \\
\text { Education Group }\end{array}$} & \multicolumn{3}{|c|}{$\begin{array}{c}\text { Routine } \\
\text { Education Group }\end{array}$} & \multirow{2}{*}{$\begin{array}{l}\text { Maximum } \\
\text { score }\end{array}$} & \multirow{2}{*}{$\begin{array}{c}\text { Statistical analysis } \\
\text { of difference } \\
\text { between groups } \\
(t \text { test })\end{array}$} \\
\hline & $n$ & Mean & SD & $n$ & Mean & SD & & \\
\hline $\begin{array}{l}\text { Nutrition terms } \\
\text { Theoretical principles } \\
\text { Practical applications }\end{array}$ & $\begin{array}{l}142 \\
142 \\
141 \ddagger\end{array}$ & $\begin{array}{l}1 \cdot 4 \\
2 \cdot 9 \\
6 \cdot 7\end{array}$ & $\begin{array}{l}1 \cdot 0 \\
1 \cdot 3 \\
1 \cdot 9\end{array}$ & $\begin{array}{l}146 \\
146 \\
145 \ddagger\end{array}$ & $\begin{array}{l}1 \cdot 4 \\
2 \cdot 7 \\
5 \cdot 9\end{array}$ & $\begin{array}{l}1 \cdot 1 \\
1 \cdot 2 \\
1 \cdot 9\end{array}$ & $\begin{array}{r}3 \\
5 \\
11\end{array}$ & $\begin{array}{l}-0 \cdot 14 \\
1 \cdot 20 \\
3 \cdot 42^{* * *}\end{array}$ \\
\hline Total score & $141 \ddagger$ & $10 \cdot 9$ & $3 \cdot 4$ & $145 \ddagger$ & $10 \cdot 0$ & $3 \cdot 2$ & 19 & $2 \cdot 41 * *$ \\
\hline
\end{tabular}

$* * P<0.01, * * * P<0.001$.

$\dagger$ The Intervention Education Group received the nutrition education programme, while the Routine Education Group did not receive the nutrition education programme. For details of subjects, see Table 2.

$\ddagger$ One person failed to complete all questions.

\section{Nutrition knowledge}

The IEG had a significantly higher score for the practical applications component and for the total score compared with the REG (Table 3). The IEG score was equal to or greater than that of the REG for every question. In both groups the poorest score was attained for one of the theoretical principles questions relating to carbohydrate ('Should people eat more/less/the same amount of starchy carbohydrate as they do at present?'). This was unanswered incorrectly by all subjects in the REG and $90 \%$ in the IEG. Three questions were answered significantly differently by the IEG than the REG. These were all from the practical applications component and related to carbohydrate ('Should people eat more/less/the same amount of (1) potatoes, (2) bread, (3) sugar?').

\section{Attitudinal factors}

The scoring for the main components of the attitudes questionnaire presented by the education group are presented in Table 4. There were no significant differences between the two groups for any of these components. However, in the estimated attitudes component (behavioural belief items $\times$ corresponding outcome evaluation items) questions relating healthier eating to reducing the risks of heart disease, maintaining health and taste scored much higher in both education groups. Similarly in the estimated subjective norm component (normative belief item $\times$ corresponding motivation to comply item), questions relating healthier eating to doctors showed a much higher score than those relating to other specific referents. There were, however, no significant differences between the two groups for any of the individual questions.

The relationships between the components of the attitudinal model were similar in both groups (Figs. 2 and 3). The overall variance in behavioural intention accounted for by the attitude and subjective norm components together was $35 \%$ in the IEG and $31 \%$ in the REG. In both groups, attitude was a better predictor of behavioural intention than subjective norm as indicated by higher beta-weights for the attitude components in the regressions shown in Figs. 2 and 3. The relationship between subjective norm and behavioural intention was stronger in the IEG $(0 \cdot 33)$ than in the REG $(0 \cdot 15)$. 
Table 4. Scoring for the components of the attitude model (based on Fishbein \& Ajzen (1975) theory of reasoned action model)* for subjects receiving the antenatal nutrition education programme (Intervention Education Group) and those who did not (Routine Education Group)

(Mean values and standard deviations)

\begin{tabular}{|c|c|c|c|c|c|c|}
\hline \multirow[t]{2}{*}{$\begin{array}{l}\text { Study group } \nmid . . . \\
n \ldots\end{array}$} & \multicolumn{2}{|c|}{$\begin{array}{c}\text { Intervention } \\
\text { Education Group } \\
142\end{array}$} & \multicolumn{2}{|c|}{$\begin{array}{c}\text { Routine } \\
\text { Education Group } \\
146\end{array}$} & \multirow{2}{*}{$\begin{array}{c}\text { Possible } \\
\text { scores }\end{array}$} & \multirow{2}{*}{$\begin{array}{c}\text { Statistical analysis } \\
\text { of difference } \\
\text { between groups } \\
\text { ( } t \text { test })\end{array}$} \\
\hline & Mean & SD & Mean & SD & & \\
\hline \multicolumn{7}{|l|}{ Component } \\
\hline Behavioural intention & $1-8$ & $1 \cdot 2$ & $1 \cdot 7$ & $1 \cdot 4$ & $-3-+3$ & 0.90 \\
\hline Direct attitudes & $7 \cdot 6$ & 3.9 & $7 \cdot 5$ & $3 \cdot 8$ & $-12-+12$ & 0.22 \\
\hline Direct subjective norm & 0.6 & $3 \cdot 2$ & 0.4 & $3 \cdot 1$ & $-6-+6$ & 0.53 \\
\hline Estimated attitude & $19 \cdot 4$ & $12 \cdot 8$ & $17 \cdot 7$ & $13 \cdot 0$ & $-54-+54$ & $1 \cdot 11$ \\
\hline Estimated subjective norm & $10 \cdot 8$ & $19 \cdot 1$ & $9 \cdot 1$ & $16 \cdot 8$ & $-72-+72$ & 0.82 \\
\hline
\end{tabular}

* For details, see Fig. 1.

$\uparrow$ For details of subjects, see Table 2.

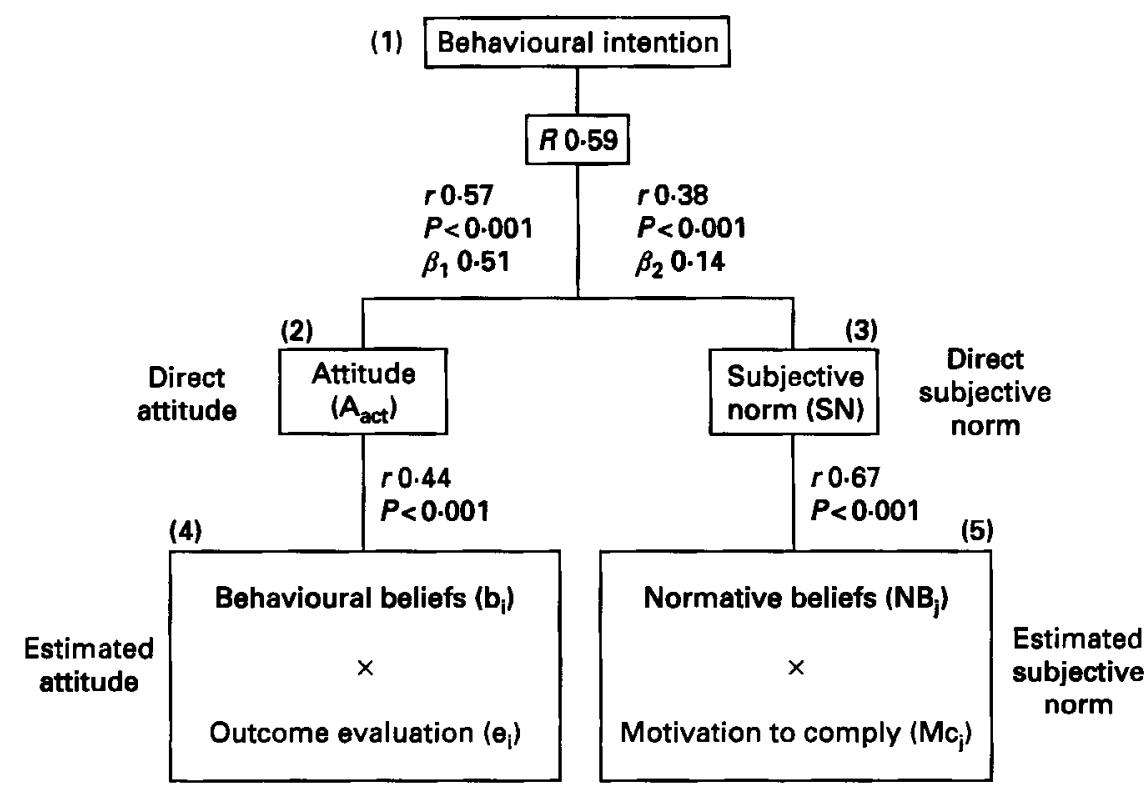

(1) Behavioural intention is used as a measure of behaviour.

(2) Attitude or personal feelings.

(3) Social pressure from other persons.

(4) Predictors of attitude component (estimated attitude).

(5) Predictors of subjective norm component (estimated subjective norm).

Fig. 2. Relationship between attitudinal components, based on the Fishbein \& Ajzen (1975) theory of reasoned action model, for the Intervention Education Group who received the nutrition education programme ( $n$ 146). Behavioural intention $=\beta_{1} \times \mathrm{A}_{\text {aet }}+\beta_{\mathrm{g}} \times \mathrm{SN}$, where $\beta_{1}$ and $\beta_{\mathrm{g}}$ are relative weightings derived from multipleregression analysis, $A_{a c t}=\Sigma b_{i} \times e_{1}$ and $S N=\Sigma N B_{j} \times M c_{j}$. For details of procedures, see pp. 165-166. 


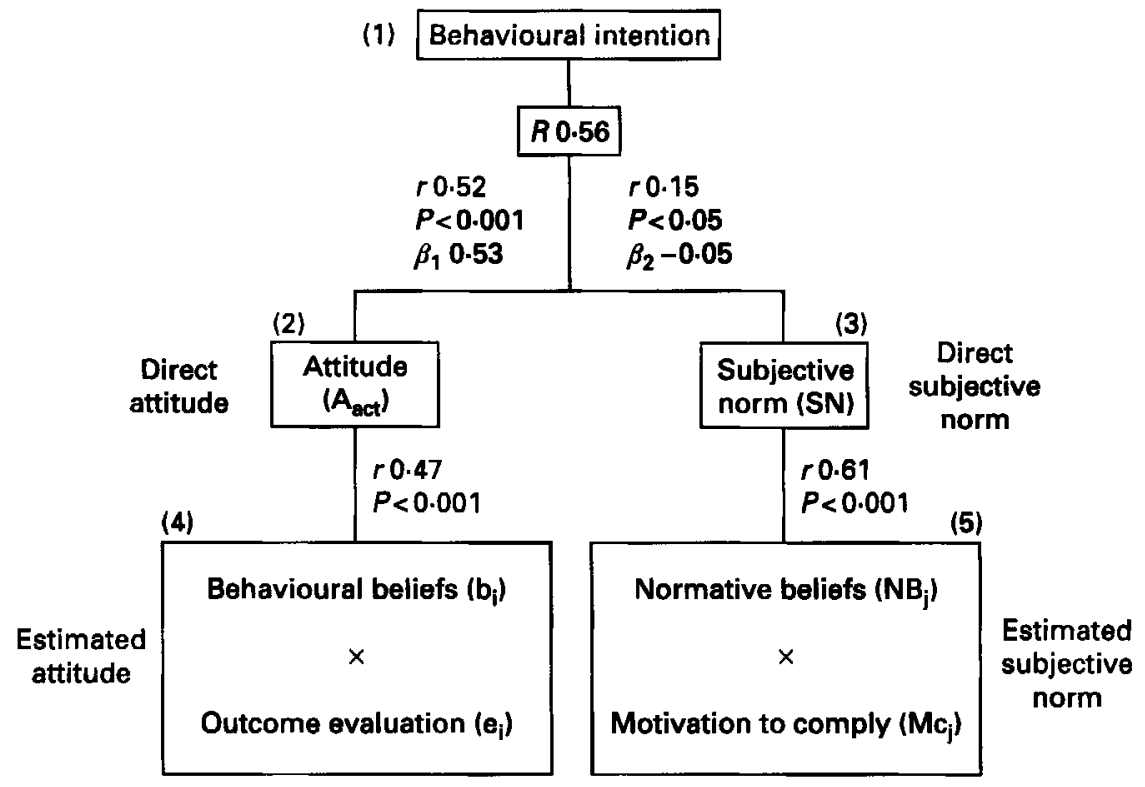

(1) Behavioural intention is used as a measure of behaviour.

(2) Attitude or personal feelings.

(3) Social pressure from other persons.

(4) Predictors of attitude component (estimated attitude).

(5) Predictors of subjective norm component (estimated subjective norm).

Fig. 3. Relationship between attitudinal components, based on the Fishbein \& Ajzen (1975) theory of reasoned action model, for the Routine Education Group who did not receive the nutrition education programme ( $n$ 142). Behavioural intention $=\beta_{1}$ and $\beta_{2}$ are relative weightings derived from multiple-regression analysis, $\mathrm{A}_{\text {act }}=$ $\Sigma \mathrm{b}_{1} \times \mathrm{e}_{1}$ and $\mathrm{SN}=\Sigma \mathrm{NB}_{\mathrm{j}} \times \mathrm{Mc}_{\mathrm{j}}$. For details of procedures, see pp. 165-166.

\section{Dietary intake}

The mean daily nutrient intakes calculated from $4 \mathrm{~d}$ diary records for 224 of 288 subjects who returned completed diaries are presented in Table 5 together with the current Department of Health (1991a) dietary reference values (DRV) for pregnancy. Nutrient intakes for all vitamins and minerals agreed with the reference nutrient intake (RNI) apart from folic acid, Fe and vitamin D. The low intake of folate may be of concern because of its possible relationship with neural-tube defects (MRC, Vitamin Study Research Group, 1991). It is recognized that in order to reach RNI levels of Fe and vitamin D women would need to take appropriate supplements (Department of Health, $1991 b$ ).

The mean daily intake of alcohol is well below that reported in dietary studies of nonpregnant women, although if non-consumers $(n 145)$ are excluded the mean daily intake increases to 3.4 (range $1 \cdot 1-15.0) \mathrm{g} / \mathrm{d}$. This is equivalent to approximately 2.5 (range $0.5-12$ ) glasses of wine per week per consumer.

The dietary fibre intake and energy composition of the diets are compared with the National Advisory Committee on Nutrition Education (1983) guidelines and Department of Health (1991a) DRV recommendations in Table 6. Dietary fibre intakes and the percentages of energy derived from fat and carbohydrate are not consistent with current guidelines for health.

Mean daily nutrient intakes for IEG and REG are presented in Table 7. There were no 
Table 5. Daily nutrient intakes from alet-diary records from subjects participating in the intervention education study to assess the effect of an antenatal nutrition education programme designed specifically for the local population $\dagger$

(Mean values and standard deviations for records from 224 subjects)

\begin{tabular}{|c|c|c|c|}
\hline & Mean & SD & $\begin{array}{c}\text { Dietary reference } \\
\text { (Department of Health, } 1991 a \text { ) }\end{array}$ \\
\hline Energy (kJ) & 9447 & 1910 & $8945-9471$ \\
\hline Protein (g) & $76 \cdot 3$ & $16 \cdot 6$ & $51^{*}$ \\
\hline Fat (g) & $99 \cdot 2$ & $25 \cdot 9$ & $\ddagger$ \\
\hline Total carbohydrate (g) & $281 \cdot 0$ & $61 \cdot 2$ & $\ddagger$ \\
\hline Sugar $(g)$ & $113 \cdot 0$ & $41 \cdot 2$ & $\ddagger$ \\
\hline Dietary fibre (g) & $20 \cdot 7$ & $7 \cdot 0$ & NA \\
\hline Alcohol (mg) & $1 \cdot 2$ & $2 \cdot 5$ & NA \\
\hline \multicolumn{4}{|l|}{ Mineral intake (mg) } \\
\hline $\mathrm{Na}$ & 3008 & 761 & 1600 \\
\hline $\mathbf{K}$ & 3384 & 756 & 3500 \\
\hline $\mathrm{Ca}$ & 1015 & 357 & 700 \\
\hline $\mathrm{Mg}$ & 314 & 82 & 270 \\
\hline $\mathbf{P}$ & 1349 & 36 & $550-625$ \\
\hline $\mathbf{S}$ & 583 & 149 & NA \\
\hline $\mathrm{Cl}$ & 4664 & 960 & 2500 \\
\hline $\mathrm{Fe}$ & $13 \cdot 0$ & $4 \cdot 6$ & $14 \cdot 8$ \\
\hline $\mathrm{Zn}$ & $9 \cdot 7$ & $2 \cdot 5$ & $7 \cdot 0$ \\
\hline $\mathrm{Cu}$ & $1 \cdot 6$ & 0.6 & $1 \cdot 0-1 \cdot 2$ \\
\hline \multicolumn{4}{|l|}{ Vitamin intake (mg) } \\
\hline Thiamin & $1 \cdot 4$ & 0.4 & $0.9^{*}$ \\
\hline Riboflavin & $2 \cdot 0$ & 0.8 & $1 \cdot 4^{*}$ \\
\hline Nicotinic acid equivalents & $19 \cdot 5$ & $5 \cdot 6$ & $13-14$ \\
\hline Vitamin C & $78 \cdot 0$ & $45 \cdot 9$ & $50^{*}$ \\
\hline Vitamin $B_{6}$ & $1 \cdot 4$ & 0.4 & $1 \cdot 2$ \\
\hline Vitamin $\mathbf{B}_{12}(\mu \mathrm{g})$ & 3.9 & $4 \cdot 1$ & $1 \cdot 5$ \\
\hline Free folate $(\mu \mathrm{g})$ & $71 \cdot 9$ & $31 \cdot 5$ & NA \\
\hline Total folate $(\mu \mathrm{g})$ & $162 \cdot 5$ & $56 \cdot 6$ & $300^{*}$ \\
\hline Pantothenic acid & $4 \cdot 2$ & $2 \cdot 7$ & NA \\
\hline Biotin & $20 \cdot 8$ & $8 \cdot 5$ & NA \\
\hline Retinol equivalents $(\mu \mathrm{g})$ & 1030 & 653 & $700^{*}$ \\
\hline Vitamin D $(\mu \mathrm{g})$ & $2 \cdot 20$ & $1 \cdot 12$ & 10 \\
\hline Vitamin $\mathrm{E}$ & $5 \cdot 60$ & $4 \cdot 38$ & NA \\
\hline
\end{tabular}

NA, not applicable (no reference nutrient intake given).

* Specific reference nutrient intake for pregnancy.

$\dagger$ For details of subjects and procedures, see Table 2 and pp. 166-167.

$\ddagger$ Dependent on energy intake.

significant differences between the two groups for mean daily nutrient intake or energy composition.

To test for differences involving more than one nutrient, the distribution of individuals achieving combinations of three dietary goals were assessed. The first was the Department of Health and Social Security (1984) recommendation that $35 \%$ of energy should be derived from fat. The second was the National Advisory Committee on Nutrition Education (1983) recommendation that $59 \%$ energy should be derived from carbohydrate. The third goal for dietary fibre was more difficult because fibre intakes in the Aberdeen population were low compared with the UK as a whole so a more realistic goal of $25 \%$ above current intake (the original proportion suggested by National Advisory Committee on Nutrition Education (1983)) was used, that is $22 \mathrm{~g}$ dietary fibre/d. The percentage of 
Table 6. Daily intake of dietary fibre and energy composition in 224 pregnant women participating in the nutrition education study compared with nutritional guidelines for longterm health (National Advisory Committee on Nutrition Education, 1983; NACNE) and dietary reference values for food energy (Department of Health, $1991 \mathrm{a} ; \mathrm{DOH}$ )

(Mean values and standard deviations)

\begin{tabular}{|c|c|c|c|c|c|}
\hline & \multirow[b]{2}{*}{ Mean } & \multirow[b]{2}{*}{ SD } & \multicolumn{2}{|c|}{ NACNE } & \multirow[b]{2}{*}{ DOH } \\
\hline & & & $\begin{array}{l}\text { Short-term goal } \\
\text { for } 1980 \mathrm{~s}\end{array}$ & $\begin{array}{l}\text { Long-term } \\
\text { goal }\end{array}$ & \\
\hline \multicolumn{6}{|c|}{$\begin{array}{l}\text { Energy composition } \\
(\text { (energy \%) }\end{array}$} \\
\hline Protein & 13 & 2 & 11 & 11 & $15^{*}$ \\
\hline Fat & 39 & 5 & 34 & 30 & 35 \\
\hline Carbohydrate & 47 & 5 & 50 & 55 & 50 \\
\hline Alcohol & Negligible & - & $\leqslant 5$ & $\leqslant 4$ & - \\
\hline Dietary fibre (g) & 21 & 7 & 25 & 30 & NA \\
\hline
\end{tabular}

NA, not applicable (no specific guideline given).

* Dietary reference value is above reference nutrient intake.

individuals achieving these goals is shown in Table 8. Numbers of women achieving such goals were small in both groups, but significantly more in the IEG achieved the combination of all three goals (carbohydrate, fat and dietary fibre) and the combination of fat and dietary fibre goals.

\section{DISCUSSION}

The principal aim of the present study was to measure the response to nutrition education in pregnant women, a target group which has been described as 'well motivated', 'interested in health education' and 'seeking health information'. The education programme was not designed to influence maternal and neonatal health statistics at the end of pregnancy or long-term health and disease prospects (e.g. reducing the risk of cardiovascular disease). Similarly, the effect of educational intervention in pregnancy on changes in nutrition knowledge, attitude or behaviour later in life were not studied but might be interesting to consider later. In its broadest sense the present study documents the response of pregnant women in Scotland to nutrition advice. Both groups studied were matched for main socio-demographic characteristics and smoking behaviour. The differences in age between the groups may have influenced the nutrition knowledge results, but it seems unlikely that younger women would have a better knowledge of nutrition because they are less exposed to diet and health concepts which older women might well be more concerned about. Dietary education in schools is not widespread (Anderson et al. 1994) in the West of Scotland.

Differences between education groups could reflect the responses of pregnant women to nutrition educational strategies which might practically be implemented using the antenatal care system. The impact of nutrition education is reflected in the higher score for the practical applications component of the nutrition knowledge questionnaire in IEG which probably relates to statements in the education programme which focussed on specific practical advice on how to achieve a low-fat diet high in fibre-rich carbohydrate, e.g. "eat more bread, don't be frightened to have 5 or more slices each day' and 'try to have boiled or baked potatoes at least five times per week' and 'eat larger portions (of potatoes)'.

Results from multiple-regression analysis show that attitudes towards healthier eating 
Table 7. Daily nutrient intake and energy composition for subjects receiving the antenatal nutrition education programme (Intervention Education Group) and those who did not (Routine Education Group)

(Mean values and standard deviations)

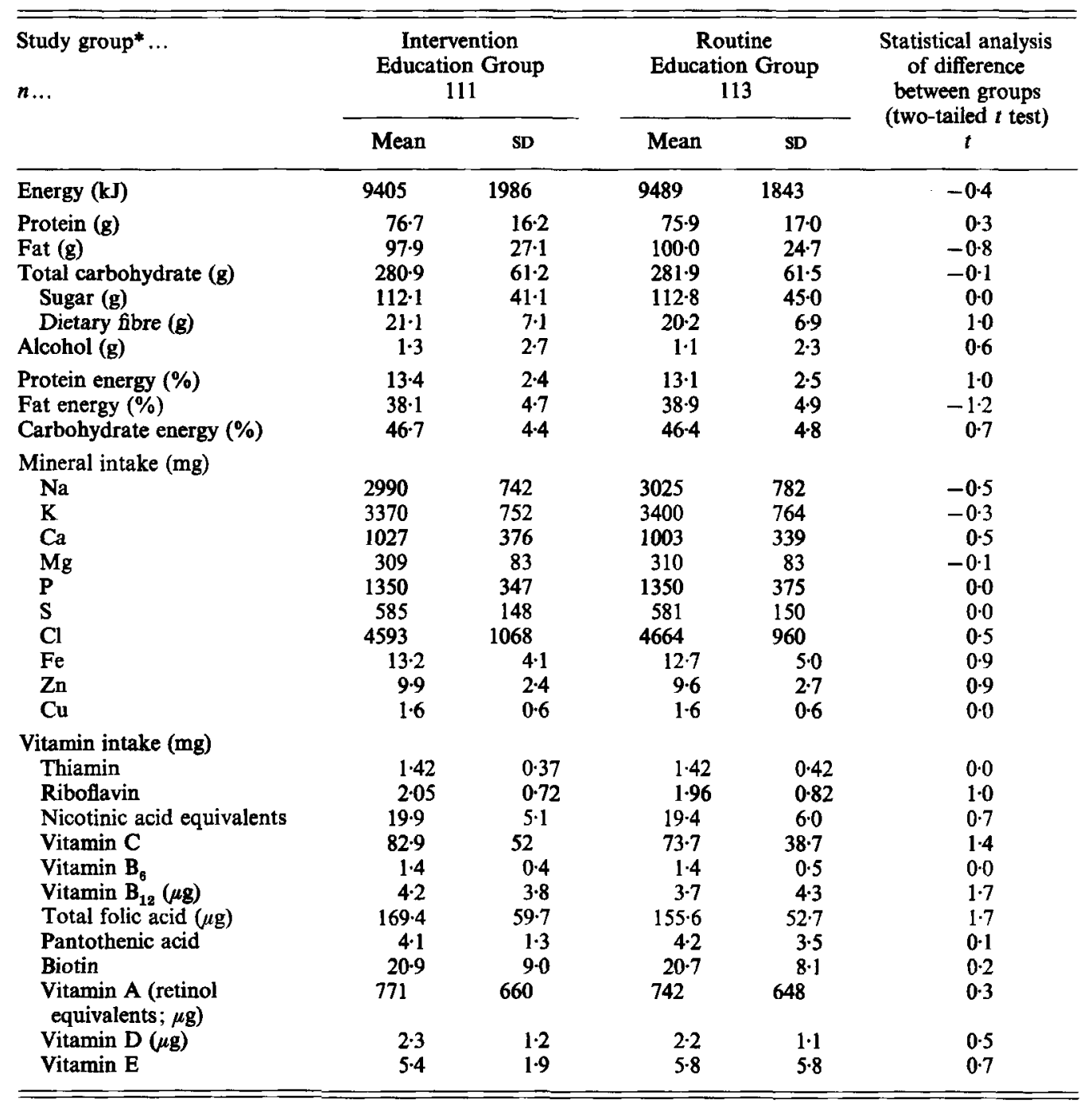

* For details of subjects and procedures, see Table 2 and pp. 166-167.

are strongly predictive of intention and that these are more important than the subjective norm component. This has also been shown in a number of other studies using this model in predicting dietary behaviour in the general population (Shepherd, 1989). It remains unclear as to how attitudes towards healthier eating can be influenced during pregnancy and whether attitude change would bring about changes in actual behaviour.

The similarity of nutrient intake between the two education groups suggests that the intervention programme was unsuccessful in changing intakes of fat, carbohydrate and dietary fibre. However, the distribution of women achieving combinations of dietary goals 
Table 8. Achievements of dietary goals for subjects receiving the antenatal nutrition education programme (Intervention Education Group) and those who did not (Routine Education Group $\dagger$

\begin{tabular}{|c|c|c|c|c|}
\hline Nutrient & Goalt & $\begin{array}{c}\text { Intervention } \\
\text { Education Group }\end{array}$ & $\begin{array}{c}\text { Routine } \\
\text { Education Group }\end{array}$ & $\begin{array}{l}\text { Statistical analysis } \\
\text { of difference } \\
\text { between groups } \\
\left(x^{2} ; 1 \text { df }\right)\end{array}$ \\
\hline$\overline{\text { Fat }}$ & $\begin{array}{l}\text { Achievers } \\
\text { Non-achievers }\end{array}$ & $\begin{array}{l}29 \\
82\end{array}$ & $\begin{array}{l}21 \\
92\end{array}$ & $\frac{2 \cdot 17}{-}$ \\
\hline Carbohydrate & $\begin{array}{l}\text { Achievers } \\
\text { Non-achievers }\end{array}$ & $\begin{array}{l}24 \\
87\end{array}$ & $\begin{array}{l}25 \\
88\end{array}$ & $\overline{0.0}$ \\
\hline Dietary fibre & $\begin{array}{l}\text { Achievers } \\
\text { Non-achievers }\end{array}$ & $\begin{array}{l}39 \\
72\end{array}$ & $\begin{array}{l}39 \\
74\end{array}$ & $\underline{0.0}$ \\
\hline Fat + carbohydrate & $\begin{array}{l}\text { Achievers } \\
\text { Non-achievers }\end{array}$ & $\begin{array}{l}14 \\
97\end{array}$ & $\begin{array}{l}17 \\
96\end{array}$ & 0.54 \\
\hline Fat + dietary fibre & $\begin{array}{l}\text { Achievers } \\
\text { Non-achievers }\end{array}$ & $\begin{array}{l}12 \\
99\end{array}$ & $\begin{array}{r}3 \\
110\end{array}$ & $\frac{10 \cdot 6^{* *}}{-}$ \\
\hline Carbohydrate + dietary fibre & $\begin{array}{l}\text { Achievers } \\
\text { Non-achievers }\end{array}$ & $\begin{array}{l}12 \\
99\end{array}$ & $\begin{array}{r}8 \\
105\end{array}$ & $\overline{3.0}$ \\
\hline $\begin{array}{l}\text { Carbohydrate }+ \text { fat }+ \\
\text { dietary fibre }\end{array}$ & $\begin{array}{l}\text { Achievers } \\
\text { Non-achievers }\end{array}$ & $\begin{array}{r}10 \\
101\end{array}$ & $\begin{array}{r}3 \\
110\end{array}$ & 6.1* \\
\hline
\end{tabular}

$* P<0.05,{ }^{* *} P<0.01$.

$\dagger$ For details of subjects and procedures, see Table 2 and pp. 166-167.

$\ddagger$ Fat $\leqslant 35 \%$ energy, dietary fibre $>22 \mathrm{~g}$, carbohydrate $>50 \%$ energy.

show a trend in the IEG towards a healthier diet in individuals. This trend clearly involved changes in one or more nutrients as promoted by the education programme. There were no apparent differences between the two education groups for sources of fat, carbohydrate and fibre despite the promotion of increased (and decreased) consumption of certain foodstuffs. This lack of difference may be accounted for by secular changes taking place in food selection irrespective of the education programme, e.g. consumption of low-fat milk is continuing to increase (Ministry of Agriculture, Food and Fisheries, 1989), although this cannot be proved from the data available in the present study. The results for nutrient intake are similar to those found in other studies of diet during pregnancy carried out in different parts of the UK (Doyle et al. 1982; Anderson \& Lean, 1986; Black et al. 1986) and in Aberdeen (Thompson et al. 1989) and have been compatible with normal physical growth and development.

In the past, much nutrition education literature for pregnancy has focussed on protein intakes. It is important that protein is not increased in order to keep the proportion of fat at $35 \%$ of energy. Protein intakes should not be increased by as much as the $40 \mathrm{~g} / \mathrm{d}$ which has been associated with early premature births and growth retardation (Rush et al. 1980). It would be preferable then if a small increase in protein could be achieved through increased consumption of breads and cereals with no specific advice being given to increase 'protein-rich foods' such as meat, fish, cheese, eggs. However, this type of diet is even less likely to be achieved by pregnant women in Aberdeen, and a reduction in fat intake equivalent to that promoted by the Committee on Medical Aspects of Food Policy (Department of Health and Social Security, 1984) (35\% energy from fat) with a corresponding increase in carbohydrate intake to at least $55 \%$ of energy would be a reasonable goal. This would satisfy general guidelines not to consume alcohol (or significant amounts) during pregnancy and maintain a low-fat diet. Given these guidelines 
the nutrient intake observed in the current study suggests that women are prepared to make changes in alcohol consumption first (presumably because this is thought to have more direct bearing on the outcome of pregnancy and/or because of taste changes occurring at this time) and changes in other nutrients follow after this. It seems unlikely that the energy deficit of alcohol is being made up by fat and the ability of this group of women to keep fat intake down to that observed in the rest of the population is encouraging.

Overall, the results for the present study suggest that written advice presented during pregnancy can influence knowledge about nutrition. The current programme has demonstrated a change in knowledge about practical aspects of current nutritional recommendations. No differences were detected in attitudinal variables which might influence nutrient intake and it is concluded that other forms of communications are necessary to achieve this goal. No differences were detected in mean nutrient intake between women who had received the intervention programme and those receiving only routine literature, which suggests that the most commonly used form of communication for nutrition advice during pregnancy designed specifically for the target population has no more effect on the nutrient intake of the population than a few words buried in the depth of a large health education text. Neither approach succeeded in assisting women to eat a low-fat, high-carbohydrate, fibre-rich diet.

The failure to demonstrate a clear relationship between nutrition knowledge and dietary intake suggests that factors other than information alone are needed to bring about dietary change. In particular the role of attitudinal factors to such change during pregnancy remains undocumented.

The authors would like to thank antenatal staff at Aberdeen Maternity Hospital for supporting and encouraging this work, Andrew Walker, AFRC Institute for Food Research, Norwich, for assistance with dietary analysis, and Mrs Lorna Hudson for secretarial help. Funding for this study was provided by The Health Promotion Research Trust.

\section{REFERENCES}

Ajzen, I. \& Fishbein, M. (1980). Understanding Attitudes and Predicting Social Behavior. Englewood Cliffs, NJ: Prentice-Hall.

Allard, J. P. (1986). Maternal nutrition for clients in the private sector. Journal of the American Dietetic Association 86, 1069-1070.

Anderson, A. S. (1991). Food and nutrition during pregnancy: Attitudes, knowledge and practice. PhD Thesis, University of Aberdeen.

Anderson, A. S., Campbell, D. \& Shepherd, R. (1993). Nutrition knowledge, attitude to healthier eating, and dietary intake in pregnant compared to non-pregnant women. Journal of Human Nutrition and Dietetics 6 , $335-353$.

Anderson, A. S. \& Lean, M. E. J. (1986). Dietary intake in pregnancy. A comparison between 47 Cambridgeshire women and current recommended intake. Human Nutrition: Applied Nutrition 40A, 40-48.

Anderson, A. S., Macintyre, S. \& West, P. (1994). Dietary patterns among adolescents in the West of Scotland. British Journal of Nutrition 71, 111-122.

Anderson, A. S. \& Shepherd, R. (1989). Beliefs and attitudes towards 'healthier eating' among women attending maternity hospital. Journal of Nutrition Education 17, 208-213.

Anderson, A. S., Umpathy, D., Palumbo, L. \& Pearson, D. W. M. (1988). Nutrition knowledge assessed by a structured questionnaire in a group of medical inpatients. Journal of Human Nutrition and Dietetics 1, 39-46.

Black, A. E., Wiles, S. J. \& Paul, A. A. (1986). The nutrient intakes of pregnant and lactating mothers of good socioeconomic status in Cambridge, UK: some implications for recommended daily allowances of minor nutrients. British Journal of Nutrition 56, 59-72.

Davison, J. S., Davison, M. C. \& Hay, D. M. (1970). Gastric emptying time in late pregnancy and labour. Journal of Obstetrics and Gynaecology of the British Commonwealth 77, 37.

Department of Health (1991 a). Dietary Reference Values for Food Energy and Nutrients for the UK. Report on Health and Social Subjects no. 41. London: H.M. Stationary Office.

Department of Health (1991 b). Women Cautioned. Press Release 90/507. London: H.M. Stationery Office. 
Department of Health and Social Security (1984). Diet and Cardiovascular Disease. Report of the Committee on Medical Aspects of Food Policy. Report on Health and Social Subjects no. 28. London: H.M. Stationery Office.

Doyle, W., Crawford, M. A., Laurance, B. M. \& Drury, P. (1982). Dietary survey during pregnancy in a low socio-economic group. Human Nutrition: Applied Nutrition 36A, 95-106.

Eaton, J. (1984). British Dietetic Association 'Battle of the bulge-food v money?' British Dietetic Association Newsletter 19, 1.

Edington, J., Thorogood, M., Geekie, M., Ball, M. \& Mann, J. (1989). Assessment of nutritional intake using dietary records with estimated weight. Journal of Human Nutrition and Dietetics 61, 407-414.

Eiser, C. \& Eiser, J. R. (1985). Health education of the primigravidae. Child: Care, Health and Development 11, 53-60.

Fishbein, M. \& Ajzen, I. (1975). Belief, Attitude, Intention and Behaviour: An Introduction to Theory and Research. Reading, Mass.: Addison-Wesley.

Kafatos, A. G., Vlachonikolis, I. G. \& Codrington, C. (1989). Nutrition during pregnancy: the effects of an educational intervention program in Greece. American Journal of Clinical Nutrition 50, $970-979$.

Metzler, S. \& Griffith, L. (1981). Teaching prenatal nutrition in an outpatient clinic: A change project. Issues in Health Care of Women 3, 341-357.

Ministry of Agriculture, Fisheries and Food (1990). Household Food Consumption and Expenditure: Annual Report of the National Food Survey Committee. London: H.M. Stationery Office.

MRC Vitamin Study Research Group (1991). Prevention of neural tube defects: Results of the MRC Vitamin Study. Lancet 338, 131-137.

National Advisory Committee on Nutrition Education (1983). Proposals for Nutritional Guidelines for Health Education in Britain. London: Health Education Council.

Nunally, J. C. (1983). Psychometric Theory, 2nd ed. New York: McGraw-Hill.

Olsen, J., Frische, G., Poulsen, A. O. \& Kirchheiner, H. (1989). Changing smoking, drinking, and eating behaviour among pregnant women in Denmark. Scandinavian Journal of Social Medicine 17, 277-280.

Oppenheim, A. N. (1966). Questionnaire Design and Attitude Measurement. London: Heinemann.

Parraga, I. M. (1990). Determinants of food consumption. Journal of American Dietetic Association 90, 661-663.

Paul, A. A. \& Southgate, D. A. T. (1978). McCance and Widdowson's The Composition of Foods. London: H.M. Stationery Office.

Rush, D., Stein, Z. \& Susser, M. (1980). A randomized controlled trial of prenatal nutritional supplementation in New York City. Pediatrics 65, 683-697.

Schifter, D. E. \& Ajzen, I. (1985). Intention, perceived control, and weight loss: an application of the theory of planned behavior. Journal of Personality and Social Psychology 49, 843-851.

Scottish Health Education Group (1980). The Book of the Child, p. 13. Edinburgh: Scottish Health Education Group.

Shepherd, R. \& Stockley, L. (1985). Fat consumption and attitudes towards food with a high fat content. Human Nutrition: Applied Nutrition 39A, 431-442.

Shepherd, R. \& Stockley, L. (1987). Nutrition knowledge, attitudes, and fat consumption. Journal of the American Dietetic Association 87, 615-619.

Shepherd, R. (editor) (1989). Factors influencing food preferences and choice. In Handbook of the Psychophysiology of Human Eating, pp. 3-24. Chichester: Wiley.

Smithells, R. W., Ankers, C. \& Carver, M. E. (1977). Maternal nutrition in early pregnancy. British Journal of Nutrition 38, 497.

Stevens, M. (1990). Strategies to influence nutrition behaviour. Journal of Human Nutrition and Dietetics 3 , 183-198.

Talmage, H. \& Reisner, S. P. (1981). Validity and reliability issues in measurement instrumentation. Journal of Nutrition Education 13, 83-85.

Tan, S. J., Wenlock, R. W. \& Buss, D. H. (1985). Immigrant Foods. Second Supplement to McCance and Widdowson's The Composition of Foods. London: H.M. Stationery Office.

Tesser, A. \& Shaffer, D. R. (1990). Attitudes and attitude change. Annual Review of Psychology 41, 479-523.

Thompson, B., Skipper, D., Fraser, C., Hewitt, A. \& Hunter, D. (1989). Dietary intake of Aberdeen primigravidae in 1950/51 and 1984/85. Journal of Human Nutrition and Dietetics 2, 345-359.

Tuorila, H. (1987). Selection of milks with varying fat contents and related overall liking, attitudes, norms and intentions. Appetite 8, 1-14.

Waterson, E. J. \& Murray-Lyon, I. M. M. (1989). Drinking and smoking patterns amongst women attending an antenatal clinic - II. During pregnancy. Alcohol and Alcoholism 24, 163-173.

Wiles, S. J., Nettleton, P. A., Black, A. E. \& Paul, A. A. (1980). The nutrient composition of some cooked dishes eaten in Britain: A supplementary food composition table. Human Nutrition: Applied Nutrition 34, $189-223$. 